\title{
Crystal structure of barium antimony lead bismuth oxide, $\mathbf{B a}\left(\mathbf{P b}_{0.63} \mathrm{Sb}_{0.26} \mathbf{B i}_{0.11}\right) \mathbf{O}_{3}$
}

\author{
O. Moretzki*,I, T. Doering ${ }^{1}$, M. Steins ${ }^{1}$, M. Wendschuh-Josties ${ }^{\mathrm{II}}$ and K. Bente \\ 1 Universität Leipzig, Institut für Mineralogie, Kristallographie und Materialwissenschaft, Scharnhorststr. 20, D-04275 Leipzig, Germany \\ II Universität Bremen, AK Kristallographie im FB 5 (Geowissenschaften), Klagenfurter Str., D-28359 Bremen, Germany
}

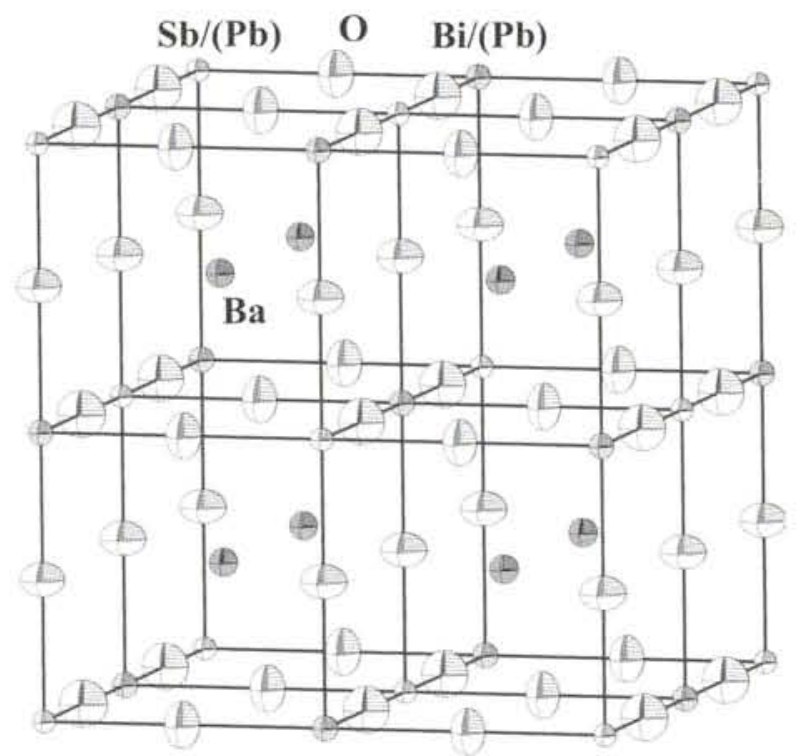

\begin{abstract}
$\mathrm{BaBi}_{0.11} \mathrm{O}_{3} \mathrm{~Pb}_{0.63} \mathrm{Sb}_{0.26}$, cubic, $F m \overline{3} m$ (No. 225),

$a=8.536(1) \AA, V=622.0 \AA^{3}, Z=8, R_{\mathrm{gt}}(F)=0.033$, $w R_{\text {all }}\left(F^{2}\right)=0.119, T=293 \mathrm{~K}$.
\end{abstract}

\section{Source of material}

Single crystals (up to $1 \mathrm{~mm}^{3}$ ) were grown by $\mathrm{PbO}$-flux in platinum crucibles with $\mathrm{Pb}$-, $\mathrm{Sb}$ - and $\mathrm{Bi}$-oxides and $\mathrm{Ba}$-carbonate as starting materials cooled down from $1420 \mathrm{~K}$ to $1020 \mathrm{~K}$ with $2-4 \mathrm{~K} / \mathrm{h}[1]$.

The chemical composition $\mathrm{BaPb}_{0.63(1)} \mathrm{Sb}_{0.26(1)} \mathrm{Bi}_{0.11(1)} \mathrm{O}_{3}$ was determined by electron microprobe analysis (Cameca SX 100). In spite of the excess of $\mathrm{PbO}$ as flux the requested $\mathrm{Pb}$-content decreased about $10 \%$ in the crystals in respect to the starting composition $\mathrm{BaPb}_{0.7} \mathrm{Sb}_{0.2} \mathrm{Bi}_{0.1} \mathrm{O}_{3}$. That was only determined in Sb-bearing crystals of the $\mathrm{Ba}(\mathrm{Pb}, \mathrm{Bi}, \mathrm{Sb}) \mathrm{O}_{3}$ system. The crystals were homogeneous and didn't show zonations, twinnings or intergrowth sections as known for other compositions.

\section{Experimental details}

The site occupancy factors were refined using some restraints as follows: The sum of the elements on the octahedral sites $(0,0,0)$ and $(1 / 2,1 / 2,1 / 2)$ corresponds to the chemical composition determined by electron microprobe analysis. Furthermore the sum of the elements on both octahedral sites must be 1 . Therefore all e.s.d's concering these elements have the same values which are small because of the good agreement of the model and the refined parameters.

\section{Discussion}

$\mathrm{Ba}\left(\mathrm{Pb}_{0.63} \mathrm{Sb}_{0.26} \mathrm{Bi}_{0.11}\right) \mathrm{O}_{3}$ single crystals show a face centered cubic superstructure resulting from an ordering of $\mathrm{Sb}$ vs. $\mathrm{Bi}$ on the octahedral site producing an eightfold perovskite cell. The space group $F m \overline{3} m$ belongs to the zero-tilt system No. 23 [2] with cation ordering. Additional measurements with synchrotron radiation (HASYLAB at DESY, Hamburg) near the $\mathrm{Pb}$ absorption edge in order to separate $\mathrm{Pb}$ and $\mathrm{Bi}$ using the anomalous dispersion [3] showed a statistical distribution of the $\mathrm{Pb}$-cations on the octahe$\mathrm{dral}$ sites. The site occupancy factors of the $\mathrm{Pb}$-cations were fixed during refinement. No exchange of $\mathrm{Pb}$ on the cubooctahedral $\mathrm{Ba}$-site was determined. Further investigations of superstructures vs. chemical composition and microscopic reflection colour related to electronic states were carried out [4].

Table 1. Data collection and handling.

$\begin{array}{ll}\text { Crystal: } & \text { black, wedge-shaped fragment, } \\ & \text { size } 0.14 \times 0.21 \times 0.28 \mathrm{~mm} \\ \text { Wavelength: } & \text { Mo } K_{\alpha} \text { radiation }(0.71073 \AA) \\ \mu: & 548.98 \mathrm{~cm}^{-1} \\ \text { Diffractometer, scan mode: } & \text { Siemens P4, } \omega \\ 2 \theta_{\max }: & 89.9^{\circ} \\ N(h k l)_{\text {measured }} N(h k l)_{\text {unique: }}: & 3182,113 \\ \text { Criterion for } I_{\text {obs }}, N(h k l)_{\text {gt }}: & I_{\text {obs }}>2 \sigma\left(I_{\text {obs }}\right), 112 \\ N(\text { param })_{\text {refined: }} & 10 \\ \text { Programs: } & \text { SHELXS-90 [5], SHELXL-93 [6] }\end{array}$


Table 2. Atomic coordinates and displacement parameters (in $\AA^{2}$ ).

\begin{tabular}{|c|c|c|c|c|c|c|c|c|c|c|c|}
\hline Atom & Site & Occ. & $x$ & $y$ & $z$ & $U_{11}$ & $U_{22}$ & $U_{33}$ & $U_{12}$ & $U_{13}$ & $U_{23}$ \\
\hline $\mathrm{Ba}(1)$ & $8 c$ & & $1 / 4$ & $1 / 4$ & $1 / 4$ & $0.0184(2)$ & $U_{11}$ & $U_{11}$ & 0 & 0 & 0 \\
\hline $\mathrm{Pb}(1)$ & $4 a$ & 0.63 & 0 & 0 & 0 & $0.0138(2)$ & $U_{11}$ & $U_{11}$ & 0 & 0 & 0 \\
\hline $\mathrm{Sb}(1)$ & $4 a$ & $0.3709(3)$ & 0 & 0 & 0 & 0.0138 & $U_{11}$ & $U_{11}$ & 0 & 0 & 0 \\
\hline $\mathrm{Bi}(1)$ & $4 a$ & 0.0000 & 0 & 0 & 0 & 0.0138 & $U_{11}$ & $U_{11}$ & 0 & 0 & 0 \\
\hline $\mathrm{Pb}(2)$ & $4 b$ & 0.63 & $1 / 2$ & $1 / 2$ & $1 / 2$ & $0.0126(2)$ & $U_{11}$ & $U_{11}$ & 0 & 0 & 0 \\
\hline $\mathrm{Sb}(2)$ & $4 b$ & $0.1489(4)$ & $1 / 2$ & $1 / 2$ & $1 / 2$ & 0.0126 & $U_{11}$ & $U_{11}$ & 0 & 0 & 0 \\
\hline $\mathrm{Bi}(2)$ & $4 b$ & 0.2212 & $1 / 2$ & $1 / 2$ & $1 / 2$ & 0.0126 & $U_{11}$ & $U_{11}$ & 0 & 0 & 0 \\
\hline$O(1)$ & $24 e$ & & $0.246(1)$ & 0 & 0 & $0.026(4)$ & $0.049(4)$ & $U_{22}$ & 0 & 0 & 0 \\
\hline
\end{tabular}

\section{References}

I. Cava, R. J.; Batlogg, B.; Espinosa, G. P.; Ramirez, A. P.; Krajewski, J. J.; Peck, Jr., W. F.; Rupp, Jr., L. W.; Cooper, A. S.: Superconductivity at 3.5 $\mathrm{K}$ in $\mathrm{BaPb}_{0.75} \mathrm{Bi}_{0.25} \mathrm{O}_{3}$ - why is Tc so low? Nature 339 (1989) 291-294.

2. Woodward, P. M.: Octahedral Tilting in Perovskites. I. Geometrical Considerations. Acta Crystallogr. B53 (1997) 32-43.

3. Wendschuh-Josties, M.: Determination of cation distributions by anomalous dispersion. Z. Kristallogr. 209 (1994) 107-112.
4. Moretzki, O.: Experimentelle Studien zur Kationen-Ordnung und Überstrukturbildung in $\mathrm{Ba}(\mathrm{Ba}, \mathrm{Pb}, \mathrm{Bi}, \mathrm{Sb}) \mathrm{O}_{3}$-Perowskiten - Röntgenbeugung und Anwendung der Synchrotronstrahlung -. Ph. D. Thesis, University of Leipzig, Germany 1999.

5. Sheldrick, G. M.: Phase Annealing in SHELX-90: Direct Methods for Larger Structures. Acta Crystallogr. A46 (1990)467-473.

6. Sheldrick, G. M.: SHELXL-93, a program for refining crystal structures. University of Göttingen, Germany 1993. 